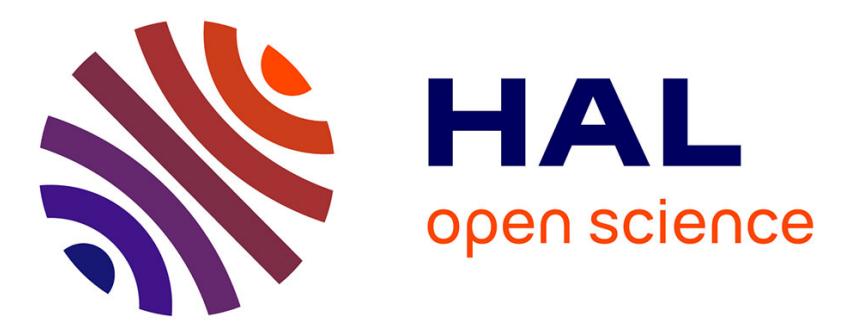

\title{
Pesticide contamination interception strategy and removal efficiency in forest buffer and artificial wetland in a tile-drained agricultural watershed
}

Elodie Passeport, Julien Tournebize, Cédric Chaumont, Angeline Guenne, Yves Coquet

\section{To cite this version:}

Elodie Passeport, Julien Tournebize, Cédric Chaumont, Angeline Guenne, Yves Coquet. Pesticide contamination interception strategy and removal efficiency in forest buffer and artificial wetland in a tile-drained agricultural watershed. Chemosphere, 2013, 91 (9), pp.1289-1296. 10.1016/j.chemosphere.2013.02.053 . insu-00853418

\section{HAL Id: insu-00853418 \\ https://hal-insu.archives-ouvertes.fr/insu-00853418}

Submitted on 3 Sep 2014

HAL is a multi-disciplinary open access archive for the deposit and dissemination of scientific research documents, whether they are published or not. The documents may come from teaching and research institutions in France or abroad, or from public or private research centers.
L'archive ouverte pluridisciplinaire HAL, est destinée au dépôt et à la diffusion de documents scientifiques de niveau recherche, publiés ou non, émanant des établissements d'enseignement et de recherche français ou étrangers, des laboratoires publics ou privés. 


\section{Pesticide contamination interception strategy and}

\section{removal efficiency in forest buffer and artificial}

\section{wetland in a tile-drained agricultural watershed}

*Elodie PASSEPORT ${ }^{\mathrm{a}, 1}$, Julien TOURNEBIZE ${ }^{\mathrm{a}}$, Cédric CHAUMONT ${ }^{\mathrm{a}}$, Angeline GUENNE ${ }^{\mathrm{a}}$, Yves COQUET $^{\mathrm{b}}$

${ }^{\text {a }}$ Research Unit Hydrosystems and Bioprocesses, IRSTEA, 1 rue Pierre-Gilles de Gennes, CS 10030, 92761 Antony Cedex, France

${ }^{\mathrm{b}}$ AgroParisTech, UMR 1091 EGC, BP 01, 78850 Grignon, France.

\section{Corresponding Author}

*passeport@es.utoronto.ca

${ }^{1}$ Present address : University of Toronto, 22 Russell St, Earth Science Center 1066, Toronto, Ontario M5S 3B1, Canada. Phone: 001 416-978-0549. Fax: 001 416-978-3839. 


\begin{abstract}
Pesticide pollution is a major threat to aquatic ecosystems that can be mitigated through complementary actions including buffer zones (BZ). This paper discusses the results of $3 \mathrm{yr}$ of field-scale monitoring of the concentration and load transfer of 16 pesticides out of a tile-drained catchment (Bray, France) and their reduction through two BZ: an artificial wetland (AW) and a forest buffer (FB). Typically, the highest concentrations were measured in the first flows following pesticide applications or resuming after periods of low or no flow. An open/close water management strategy was implemented to operate the parallel BZ based on pesticide applications by the farmer. The strategy was efficient in intercepting molecules whose highest concentrations occurred during the first flows following application. Inlet vs. outlet pesticide load reductions ranged from 45 to $96 \%(\mathrm{AW})$ and from -32 to $100 \%(\mathrm{FB})$ depending on the pesticide molecule and the hydrological year. Partly reversible adsorption was a dominant process explaining pesticide removal; whereas, degradation occurred for sufficiently long water retention time. Apart from the least sorbing molecules (e.g., isoproturon), BZ can partially remove pesticide pollution.
\end{abstract}

Keywords: Wetland, forest, pesticide, non-point source pollution

\title{
1. Introduction
}

Agricultural tile drainage and surface runoff waterways are the most important contributors to pesticide transport to aquatic ecosystems (Carter, 2000). Creation or restoration of buffer zones (BZ) such as vegetal filter strips, constructed wetlands, detention ponds, and use of pre-existing landscape elements such as forests, grassed areas or hedges have been considered practical and efficient tools for pesticide pollution mitigation (Gregoire et al., 2009). Their 
location in the landscape should be part of a broad approach encompassing complementary actions including those dealing with farming practices at different scales (van der Valk and Jolly, 1992). Most BZ are in-stream systems, situated in series with contaminated flows, thus receiving all water volumes. In Europe, reduced land availability is a major constraint, possibly resulting in problems dimensioning BZ that can collect and treat all watershed outlet flows. One solution is to set up off-stream BZ, placed parallel to agricultural ditches. Associated with by-pass structures, one can thus select a portion of catchment flows to be treated. In tile-drained catchments, drainage pipe outlet locations are well known and easy to divert and thus particularly well adapted to implementing such off-stream actions.

Among BZ, the forest buffer (FB)'s potential to reduce pesticide concentrations and loads has been investigated by a limited number of studies (Lowrance et al. 1997; Vellidis et al., 2002; Gay et al., 2006; Pinho et al. 2007). Although high levels of pesticide reduction have been indicated by these papers, it should be noted that they were all conducted in Georgia in the United States, and three of them focused on the same research site. Low concentration reductions (28 and 5\%) but moderate load reductions (47 and 28\%) were observed for two moderately sorbing herbicides, atrazine and picloram, respectively (Pinho et al., 2007). These authors suspected a low level of sorption and degradation processes and a major role played by infiltration in explaining these results.

Despite attributed large pollution mitigation efficiencies (50-80\%), artificial wetlands (AW, also called constructed wetlands) exhibit a wide range of reduction efficiency (Braskerud and Haarstad, 2003; Gregoire et al., 2009). It should be noted that a significant number of studies researched highly sorbing insecticides for which weakly reversible adsorption mainly governs their removal from the water column (Moore et al., 2009). Under alternation of aerobic and 
anoxic conditions due to water level fluctuations, pesticide removal processes include microbeand plant-mediated volatilization, plant uptake and phytoaccumulation, adsorption, sedimentation of particle-bound molecules, and phyto-, microbial and chemical degradation (Imfeld et al., 2009). The literature has few studies on newly released molecules and rarely assesses constructed wetland efficiency under realistic low or moderate concentrations (Moore et al., 2000). In addition, the subsurface tile-drainage context is poorly documented, despite its widespread use in Northern Europe and the central and eastern parts of the USA. Finally, whereas limited land availability for buffer zone implementation is a recurrent problem in Europe, to our knowledge, no study has evaluated the overall impact of off-stream systems on total watershed outlet pesticide pollution.

The objectives of this paper are (1) to characterize pesticide transfer dynamics in a tiledrained catchment; (2) to assess the efficiency of (i) a constructed wetland and (ii) a FB for the removal of 16 pesticides encompassing moderately sorbing and slightly mobile molecules; (3) to evaluate a novel strategy for intercepting contaminated flows in a tile-drained agricultural watershed; (4) to calculate uncertainties on pesticide concentrations and loads; and (5) to discuss pesticide removal processes in these two types of BZ.

\section{Materials and methods}

\subsection{Site description}

The Bray 46-ha agricultural tile-drained watershed has a hydromorphic Gleyic Luvisol soil above a clay-with-flint layer. The farmer occupying the whole watershed mainly grows rapeseed, wheat and barley. On average, 24 different pesticide molecules are applied every year, dominated by herbicides ( $80 \%)$ and fungicides $(20 \%)$. When accounting for every molecule 
applied over the past $8 \mathrm{yr}$, average yearly applications were 94 (herbicides) and $132 \mathrm{~kg}$ (fungicides) on the Bray catchment. For instance, isoproturon, chlorotoluron and metazachlor ( $\mathrm{K}_{\mathrm{oc}}$ sorption coefficient $<200 \mathrm{~mL} \mathrm{~g}^{-1}$, herein referred to as "moderately sorbing", Table 1) were associated with large applied doses $\left(>700 \mathrm{~g} \mathrm{ha}^{-1} \mathrm{yr}^{-1}\right)$, whereas diflufenican and epoxiconazole $\left(\mathrm{K}_{\mathrm{oc}}\right.$ sorption coefficient $>1000 \mathrm{~mL} \mathrm{~g}^{-1}$, herein referred to as "slightly mobile", Table 1) were applied in smaller quantities $\left(<70 \mathrm{~g} \mathrm{ha}^{-1} \mathrm{yr}^{-1}\right)$ (see Supplementary Material (SM) Fig. SM-1).

At the outlet of the Bray catchment, parallel to the main agricultural ditch, a FB and a three-cell in a series AW were implemented off-stream in December 2007 (Fig. 1). The BZ surface areas covered $1600(\mathrm{FB})$ and $1280 \mathrm{~m}^{2}(\mathrm{AW})$, each one accounting for less than $0.5 \%$ of the watershed surface area. The AW water level varied from 20 to $80 \mathrm{~cm}$ while the water storage capacity was $330 \mathrm{~m}^{3}$, representing approx $7 \mathrm{~m}^{3}$ of storage capacity per catchment ha. Vegetation progressively covered from 10 (2008) to 70\% (2010) of the wetland surface, approximately. A flora inventory conducted in 2009 showed dominance of tall aquatic plants, namely Glyceria maxima (53\%), Festuca arundinacea (12\%), Phragmites australis (10\%) and Phalaris aundinacea (9\%). The FB consisted of common oak trees (Quercus robur). An inlet ditch distributed water through the FB as a sheet-flow not exceeding $5 \mathrm{~mm}$ in depth. An outlet ditch collected runoff and diverted it back to the agricultural ditch and the river (Fig. 1).

Due to their limited surface areas, the BZ could not collect and treat all watershed outlet volumes. Consequently, only a portion of watershed outlet flows was forced to cross the systems based on a novel strategy herein referred to as the "open/close strategy" using PVC pipes, 200$\mathrm{mm}$ in diameter, equipped with movable elbows. They were located at the catchment outlet corresponding to the buffer zone inlet, in the agricultural ditch, approximately $120 \mathrm{~m}$ upstream of Le Calais stream (Fig. 1). Down-turned, the pipes diverted watershed outlet flows (WSout) to the 
buffer zone inlets (FBin and AWin) (Fig. 1). Conversely, while the pipes were up-turned, water could not pass through the systems and reached the stream directly via the agricultural ditch (the "Ditch" route in Fig. 1). The BZ were opened by the farmer himself by down-turning pipe elbows after he applied pesticides. This use ensured that the first flows following applications, typically associated with the highest pesticide concentrations and loads, were intercepted by the BZ. Figure 2 shows the periods when each buffer zone was open.

\subsection{Material}

The volumes of water coming out of the Bray catchment can either enter one or both of the BZ or flow straight through the main ditch down to Le Calais stream. Three flow paths are therefore possible for the watershed outlet flows according to buffer zone openings and closings (Fig. 1). Consequently, total flow measurement coming out of the watershed was obtained from different equipment. A controlled section was installed in the agricultural ditch where the water level was related to the flow rate by a frequently verified third-order calibration equation. An electromagnetic flow meter (MAG 8000 SIEMENS) was set up inside PVC pipes at the inlet of each mitigation system. Due to pipe diameters, the maximal inlet flow rates were 35 (AW) and 9 $\mathrm{L} \mathrm{s}^{-1}(\mathrm{FB})$.

Continuously from November 2007, flow-weighted composite samples were taken at the watershed and BZ outlets by means of ISCO 3700 automatic samplers and collected approx every week. Water samples were frozen until analysis. Samples were filtered $(0.20 \mu \mathrm{m}$ PET 20/15 MS Macherey-Nagel CHROMAFIL syringe filters), underwent a solid-phase microextraction (SPME) and were analyzed using a multi-residue gas chromatography-mass 
spectrometry (GC - MS, Trace DSQ, Thermo-Fisher Scientific) analytical method. Analytical method development, validation and uncertainty calculations have been fully detailed in Passeport et al. (2010a). This analytical method enabled the simultaneous determination of 16 pesticides in water; their main characteristics are presented in Table 1. The limits of quantification (LQ) were $0.05,0.1$ or $0.5 \mu \mathrm{g} \mathrm{L}{ }^{-1}$ depending on the molecule. Composite samples of sediment grab subsamples were taken once (March 2009) in the AW and the FB and analyzed for pesticide concentrations by the Institut Pasteur de Lille (France) for isoproturon, metazachlor, cyproconazole and epoxiconazole $\left(\mathrm{LQ}=0.01 \mathrm{mg} \mathrm{kg}^{-1}\right)$.

\subsection{Data analysis}

Field monitoring was designed in a way that 3-yr data comprising of flow rates, volumes, pesticide concentrations and loads, were collected at five locations: watershed outlet, AW and FB inlets and outlets.

\section{Efficiency assessment}

As mentioned above, samples were collected approximately every week. Loads (L) of each pesticide $\mathrm{j}\left(\mathrm{L}_{\mathrm{j}}, \mathrm{mg}\right)$ were calculated for each flow-weighted composite sample by multiplying pesticide $\mathrm{j}$ concentration $\left(\mathrm{C}_{\mathrm{j}}, \mu \mathrm{g} \mathrm{L}{ }^{-1}\right)$ by volume $(\mathrm{V})$ that passed at the measuring station (inlet or outlet) during the sampling period $(\delta \mathrm{t})$ with a flow-rate $\mathrm{Q}(\mathrm{t})(\mathrm{Eq}$. 1) and determined using the trapezoidal method.

$$
L_{j}(t)=\int_{t=0}^{t=\delta t} C_{j} \times Q(t) \times d t
$$


Total pesticide loads over $1 \mathrm{yr}$ and over the whole monitoring period were also calculated by summing individual sample loads during the corresponding period. Missing concentrations were replaced with the averages of the previous and next concentrations. In addition, data below the limit of detection (LD) were replaced with zeros; whereas data below the limit of quantification were replaced with LQ divided by 2, assuming a uniform distribution (GUM 1999).

The combination of the buffer zone off-stream position and the open/close strategy resulted in only a portion of watershed outlet pollution passing through and being treated by the artificial wetland and forest buffer. A global assessment of the systems' efficiency was conducted (i) by calculating the concentration and load reductions, as presented in Eq. 2 and 3, respectively, for each buffer zone, and (ii) by reporting removed pesticide pollution in each buffer zone $\left(L_{j_{-} B \text { Binlet }}-L_{j_{-} B \text { BZoutlet }}\right)$ to that measured at the catchment outlet $\left(L_{j_{-} \text {WSoutlet }}\right)$ (Eq. 4$)$.

$$
\begin{aligned}
& \eta_{C_{j}}=100 \times \frac{C_{j_{-} \text {inlet }}-C_{j_{-} \text {outlet }}}{C_{j_{-} \text {inlet }}} \\
& \eta_{L_{j}}=100 \times \frac{L_{j_{-} \text {inlet }}-L_{j_{-} \text {outlet }}}{L_{j_{-} \text {inlet }}} \\
& \eta_{L_{-} B Z / W S}=100 \times \frac{\left(L_{j_{-} \text {BZinlet }}-L_{j_{-} \text {BZoutlet }}\right)}{L_{j_{-} \text {WSoutlet }}}
\end{aligned}
$$

\section{$\underline{\text { Uncertainty analyses }}$}

Uncertainties on concentrations $\left(\mathrm{u}\left(\mathrm{C}_{\mathrm{j}}\right)\right)$ were calculated with regard to two main components. First, individual uncertainties due to the whole analytical procedure including standard preparation as well as calibration model determination and use were combined as described by Passeport et al. (2010a) and were noted $\mathrm{u}_{\mathrm{an}}\left(\mathrm{C}_{\mathrm{j}}\right)$. Second, as explained above, data 
below the LQ were replaced with LQ/2 for calculation purposes, although such nonquantifiable concentrations could take any value between zero and LQ. In such cases, the best estimate of the uncertainty generated by this arbitrary choice $\left(\mathrm{u}_{\mathrm{LQ}}\left(\mathrm{C}_{\mathrm{j}}\right)\right)$ is given by Eq. 5 (GUM, 1999).

$u_{L Q}\left(C_{j}\right)=\frac{\frac{(L Q-0)}{2}}{\sqrt{3}}$

Consequently, unless concentrations were above the $\mathrm{LQ}$, in which case $\mathrm{u}_{\mathrm{LQ}}\left(\mathrm{C}_{\mathrm{j}}\right)$ was not considered, combined uncertainties on concentrations were determined as follows (Eq. 6):

$u\left(C_{j}\right)=\sqrt{u^{2}{ }_{a n}\left(C_{j}\right)+u^{2}{ }_{L Q}\left(C_{j}\right)}$

Uncertainties on loads $\left(u\left(L_{j}\right)\right)$ from samples collected weekly were obtained from Eq. 1 using the first-order Taylor series expansion. The variables were assumed to be independent, thus allowing for neglecting the covariance term (Eq. 7).

$$
u^{2}\left(L_{j}\right)=\left(\frac{\partial L_{j}}{\partial C_{j}} \cdot u\left(C_{j}\right)\right)^{2}+\left(\frac{\partial L_{j}}{\partial Q} \cdot u(Q)\right)^{2}+\left(\frac{\partial L_{j}}{\partial \delta t} \cdot u(\delta t)\right)^{2}
$$

A constant uncertainty was taken for the flow-rate $(\mathrm{u}(\mathrm{Q}))$ considering a worst-case scenario. The highest uncertainty $\left(0.0059 \mathrm{~L} \mathrm{~s}^{-1}\right)$ corresponding to the lowest recorded flow-rate $\left(0.3 \mathrm{~L} \mathrm{~s}^{-1}\right)$ was calculated from data given by the manufacturer. The uncertainty on the time period $(\mathrm{u}(\delta \mathrm{t}))$ was assumed to be null. 
Concentration and load data were presented associated with their corresponding expanded uncertainties, $\mathrm{U}\left(\mathrm{C}_{\mathrm{j}}\right)$ and $\mathrm{U}\left(\mathrm{L}_{\mathrm{j}}\right)$, respectively, determined using a coverage factor of 2 for a $95 \%$ level of confidence. Uncertainty values were given with two significant digits. The results were presented with the same number of decimals as the corresponding uncertainties (EURACHEM/CITAC, 2000).

\section{$\underline{\text { Statistical analysis }}$}

Possible significant differences between inlet and outlet loads for each buffer zone were detected by means of nonparametric one-sided paired ranked signed Mann-Whitney-Wilcoxon tests $(\alpha=0.05)$ using the $\mathrm{R}$ software (R Development Core Team, 2005). The two-sided unpaired nonparametric Mann-Whitney test $(\alpha=0.05)$ was used to detect differences between artificial wetland and forest buffer outlet concentrations and loads.

\section{Results}

\subsection{Pesticide dynamics at the watershed outlet}

\subsubsection{Concentrations}

Among the 16 pesticide molecules that could be analyzed by the SPME - GCMS analytical method, nine were applied by the farmer during the monitoring period: chlorotoluron, napropamide, diflufenican, isoproturon, epoxiconazole, aclonifen, mefenpyr-diethyl, metazachlor and prosulfocarb (Fig. SM-1). In addition, apart from prosulfocarb, all these molecules, as well as cyproconazole, were also applied from 2002 to 2007. Compared to the total applied mass of 
herbicides and fungicides employed by the farmer, 25\% (2007-2008), 41\% (2008-2009) and $52 \%$ (2009-2010) of the pesticides applied belonged to the 16 molecules analyzed using the SPME - GCMS analytical method. Consequently, even though it encompassed only a small portion of the total number of molecules (approx 20\%), a reasonable portion of pesticide masses actually spread onto the watershed was accounted for. Among the pesticides that were searched for, atrazine, chlorothalonil, prosulfocarb, fenpropidin, ethofumesate, cyproconazole and aclonifen were usually not detected and tebuconazole and mefenpyr-diethyl concentrations were between the limits of detection and quantification on some occasions.

Pesticides for which the concentrations were higher than the LQ were isoproturon (quantified in $95 \%$ of the samples), chlorotoluron (89\%), metazachlor (86\%), epoxiconazole (37\%), diflufenican (28\%) and napropamide (12\%). Concentration ranges for the most frequently quantified molecules are presented in Table 2. Observed maximal peak concentrations and associated analytical uncertainties were $88 \pm 3$ (isoproturon), $200 \pm 20$ (chlorotoluron), $4.15 \pm$ 0.23 (metazachlor), $2.27 \pm 0.13$ (epoxiconazole), $0.25 \pm 0.01$ (napropamide) and $0.64 \pm 0.05$ (diflufenican) $\mu \mathrm{g} \mathrm{L}^{-1}$.

Figure 2 illustrates the transport pattern of epoxiconazole and metazachlor as example molecules representing contrasted sorption properties (Table 1). Their concentrations in flowweighted composite samples and time-dependent samples (over a shorter sampling period) are presented in Fig. 2a and 2b, respectively. First, generally, concentrations were the highest in the first flows following pesticide applications (Fig. 2a). This was also observed for other pesticides. On some occasions, extremely high values were recorded for moderately sorbing molecules such as isoproturon $\left(88 \pm 3 \mu \mathrm{g} \mathrm{L}^{-1}\right)$ and chlorotoluron $\left(200 \pm 20 \mu \mathrm{g} \mathrm{L}^{-1}\right)$. Second, concentrations decreased from one year to another if no additional application was made, as observed for 
moderately sorbing metazachlor (Fig. 2a). However, average concentrations remained at $0.44 \pm$ $0.02 \mu \mathrm{g} \mathrm{L}^{-1}$ in 2008-2009 and $0.11 \pm 0.01 \mu \mathrm{g} \mathrm{L}^{-1}$ in 2009-2010 for this herbicide. Third, surprisingly, concentration increases were also noted occasionally when flow resumed, associated with high or moderate peak discharges, after periods of low or no flows, as shown for epoxiconazole in February 2009 (Fig. 2a) and 22 May 2009 (Fig. 2b).

\subsubsection{Loads}

Watershed outlet loads and associated uncertainties are reported in Table 3. The least sorbing molecules (e.g., isoproturon, chlorotoluron and metazachlor) were associated with the largest exported loads, exceeding $277.7 \mathrm{~g}$ (Table 3) per molecule for the whole 2007-2010 monitoring period for these three herbicides. Conversely, slightly mobile pesticides presented the lowest watershed outlet loads, totaling less than $90.1 \pm 3.8$ (epoxiconazole), $9.9 \pm 1.0$ (diflufenican) and $3.40 \pm 0.97 \mathrm{~g}$ (aclonifen) for 2007-2010. Usually, less than $2 \%$ of the applied masses were recovered yearly at the outlet of the catchment. However, higher values were measured less frequently. For instance, after metazachlor application on 3 September 2007 (3435 g on 4 ha), 6.9 (2007-2008), 1.0 (2008-2009) and 0.2\% (2009-2010) of the applied mass were recovered annually, totaling $8.1 \%$.

\subsection{Off-stream buffer zones: open/close strategy efficiency}

Via operating pipe elbows in the main ditch, the portions of watershed outlet water volumes and pesticide loads that passed through the $\mathrm{BZ}$ were $50 \%$ each in the $\mathrm{AW}$, and 9 and $6 \%$ in the FB, respectively, during the whole $2007-2010$ monitoring period.

\subsection{Buffer zone efficiency}


During the 2007-2010 monitoring period, 44 and 14 synchronic inlet-outlet pairs of samples $\left(n_{p}\right)$ were collected for the AW and the FB, respectively. The FB was open less frequently than the $\mathrm{AW}$, resulting in a smaller data set. Pesticide median concentration reductions varied greatly, ranging from negative ( $-9 \%$, isoproturon) to $79 \%$ (tebuconazole) reduction efficiencies in the AW (for $\mathrm{n}_{\mathrm{p}}>6$ ) and were associated with high standard deviations (Table SM-1).

Load reductions varied from -32 (cyproconazole) to $100 \%$ (prosulfocarb) in the FB, and 45 (isoproturon) to $96 \%$ (ethofumesate) in the AW (Table 3). All pesticides together, average load reductions of $54 \pm 31$ (FB) and $73 \pm 16 \%$ (AW) were measured. In the AW, moderately sorbing pesticides such as isoproturon or metazachlor generally presented moderate load reductions. Conversely, slightly mobile molecules (e.g., tebuconazole, epoxiconazole, diflufenican), usually applied in smaller quantities in the catchment exhibited higher load reduction values. However, this was not observed for metazachlor and chlorotoluron. Despite exhibiting moderate $\mathrm{K}_{\mathrm{oc}}$ sorption coefficients (Table 1), large load removal, exceeding $70 \%$, were noted. In 2008-2009 and 2009-2010, 90\% of buffer zone inlet water volumes were intercepted in fall and winter, the coldest seasons of the year (Fig. SM-2). The lowest (20082009) and highest (2009-2010) load reductions were recorded during these two years (Fig. SM3).

In the AW, significantly larger $(\alpha=0.05)$ inlet than outlet loads were observed for isoproturon, chlorotoluron, metazachlor, diflufenican, tebuconazole and epoxiconazole, whereas only the first three herbicides showed such differences in the FB. 
Concentrations in wetland sediments and forest soil and litter were lower than the LQ for epoxiconazole, metazachlor, cyproconazole and isoproturon in wetland sediments and only quantified at the $0.01-\mathrm{mg} \mathrm{kg}^{-1}$ threshold for isoproturon and epoxiconazole in the forest litter.

A statistically significant portion of incoming water was lost through the BZ, totaling 45 (AW) and 30\% (FB). Differences between inlet and outlet water volumes were greater in spring than winter months.

\subsection{Global impact on stream}

For the most frequently applied and quantified pesticides, load reductions were $10 \%$ for isoproturon, $21 \%$ for epoxiconazole, $32 \%$ for metazachlor, $55 \%$ for diflufenican, $41 \%$ for tebuconazole and $63 \%$ for chlorotoluron of the watershed outlet loads (Table 3). All pesticides together, the presence of the $\mathrm{BZ}$ reduced $39 \%$ of the pesticide loads measured at the Bray tiledrained catchment outlet over the whole monitoring period. The lowest and highest volumes and pesticide loads that were intercepted occurred in 2008-2009 and 2009-2010, respectively (Fig. SM-3) and were for the most part due to the AW. Water volume and pesticide load interception was more evenly distributed within the season in 2007-2008 than in the following 2 years (Fig. SM-3).

\section{Discussion}

\subsection{Pesticide concentrations and loads at the watershed outlet}

Similar detection frequencies as those observed in the present study were measured for isoproturon and metazachlor at the outlet of an artificially drained catchment in Sweden (900 ha) (Kreuger, 1998). Pesticide losses were in accordance with the values reported in the literature, 
suggesting that generally less than $0.5 \%$ of the applied pesticide mass was recovered at the subsurface drainage outlet, although higher values were occasionally measured, as noted for metazachlor (Carter, 2000). On average, pesticide concentrations were close to or lower than the European Water Directive (2000/60/EC) drinking water limit for each pesticide $\left(0.1 \mu \mathrm{g} \mathrm{L}{ }^{-1}\right)$, but above the maximal accepted value for all pesticides $\left(0.5 \mu \mathrm{g} \mathrm{L}{ }^{-1}\right)$. In addition, individual pesticide concentrations can temporarily exceed $0.1 \mu \mathrm{g} \mathrm{L}^{-1}$ thus presenting a potential risk for the aquatic life and requiring treatment should this water be used as a drinking water supply. Pesticide concentration peaks are therefore a key issue which is tackled here by BZ implementation. Molecules with moderately sorbing properties and applied in relatively large masses were associated with large exported loads (e.g., isoproturon, chlorotoluron) and may require long periods to reach low concentrations (e.g., metazachlor). Reducing applied masses or substitution of these molecules for others would avoid building up a stock in the watershed soil and would likely reduce pesticide transfer loads. Molecule properties are not the sole parameters explaining these results. As noted in other studies, temporal variations of pesticide concentrations at the watershed outlet were usually in accordance with farmer pesticide application masses and timings, as well as rain events (Kladivko et al., 2001; Branger et al., 2009). Concentration increases at the time flow resumed could be explained by contributing water flows originating from different locations in the soils at different velocities (Branger et al., 2009). Moreover, interruption in drainage flows allows for molecular diffusion of pesticides toward less concentrated zones and their subsequent rapid leaching when flow resumes (Cote et al., 2000). This phenomenon might explain the high epoxiconazole concentrations and loads measured in February 2009 when flow resumed after it had stopped during a frost period (Fig. 2a). Finally, 
most of the molecules were detected despite they were not applied by the farmer during the observation period. This suggests a likely remobilization of previously applied pesticides.

\subsection{Buffer zone efficiency}

\subsubsection{Sampling strategy}

A very wide range of concentration reductions was observed. A number of reasons can explain this variability. First, inlet-outlet synchronic pairs of samples did not necessarily encompass a whole flood due to sample collection time and buffer zone water residence time. Second, low inlet and outlet concentration values were frequently measured, leading to overlapping uncertainties. Third, given infrequent quantifications, some of the reductions in mean and median concentration of individual pesticides were calculated based on small data sets despite the 3-yr monitoring period.

In tile-drained watersheds with continuous outflow at least part of the year, concentration-based reductions calculated from weekly collected composite samples is not an appropriate means to assess buffer zone efficiencies. As a consequence, it is highly recommended to calculate pesticide loads and load reductions over longer periods (e.g., season, year). However, comparing both pesticide concentration and load reductions provides clues to understanding the underlying processes governing pesticide fate.

\subsubsection{Pesticide removal processes}

Our results showed a tendency toward greater efficiency for the most sorbing molecules and those associated with low application rates. This is corroborated with previous results. Indeed, most previous studies that concluded on large potential of constructed wetlands for 
removing pesticides focused on slightly mobile molecules (e.g., Moore et al., 2009). From one flow-weighted composite sample to the next one, pesticide retention and remobilization could have occurred. Pesticide release back to the water column from sorption sites may have led to larger outlet than inlet concentrations responsible for negative concentration reductions (Table SM-1). Such a reversible adsorption was already suggested for moderately sorbing isoproturon and metazachlor from laboratory experiments on wetland sediments, wetland plants, forest soil, and forest litter from this experimental site (Passeport et al., 2011a). The Bray FB showed lower load reduction efficiency levels than the AW, which may be due to lower water losses by infiltration in the FB than in the AW. Furthermore, the FB was not open in spring when warmer temperatures than in fall or winter may have led to greater biodegradation (top of Fig. 2a). Previous authors suggested a high potential of buffer systems including a forested area for removing moderately sorbing pesticides (Lowrance et al., 1997; Vellidis et al., 2002). Gay et al. (2006) attributed atrazine removal to infiltration and degradation in a three-zone buffer. Artificial wetland average residence time measured in March 2008 was $66.5 \mathrm{~h}$ (Passeport et al., 2010b). A longer residence time may have been reached in the last $2 \mathrm{yr}$ of monitoring due to vegetation growth. Depending on the pesticide, degradation may not have had time to reach its full extent because of reduced residence time. In addition, degradation may not have been high in winter when the wetland was full of water, the soil was anoxic and the temperature was low. Under flooded anoxic conditions, epoxiconazole degradation occurred but at a very slow rate (Passeport et al., 2011b). In addition, these authors showed that epoxiconazole forms nonextractable residues over time, which may contribute to its reduction and can also be expected for similarly hydrophobic compounds. More research is needed on the long-term accumulation of pesticides in the wetland sediments, especially for those presenting long half-life properties (e.g., 
cyproconazole, $300 \mathrm{~d}$, Table 1). However, a few attempts suggested that degradation processes can affect accumulated pesticide in BZ sediment. From March 2009 sampling campaign conducted during this study, wetland sediments and the forest soil and litter sample showed no accumulation of pesticides in their original molecular form suggesting degradation occurred or accumulated pesticide concentration was below the LQ. In another study, Maillard et al. (2011) observed that some pesticides were accumulated in wetland sediment over time, such as tetraconazole (half-life $=340 \mathrm{~d}$ in sediments, FOOTPRINT, 2010). These authors also found that for other pesticide molecules, the concentration first increased in sediment, before decreasing under degradation processes.

\subsubsection{Water losses}

In both BZ, the soil was clayey, reducing downward infiltration. However, some leaks were observed and fixed in winter 2008 (in the AW), and 2009 (FB). Wetland vegetation is known for presenting high evapotranspiration rates (Kadlec and Wallace, 2008) which is likely to explain part of observed water losses, especially for the highest losses measured in spring than in winter. The FB was frequently closed in spring, preventing extended water loss by evapotranspiration. Infiltration was shown to be the primary route driving pesticide removal through grassed buffer strips (Lacas et al., 2005). Forest buffers and grassed buffer strips present a similar functioning, although the former exhibit a thicker organic matter layer supporting pesticide adsorption and microbial degradation. In the FB, infiltration may have caused leaching of the least hydrophobic pesticides such as isoproturon and metazachlor. In order to protect groundwater and limit deep infiltration, BZ should be constructed primarily where an impervious soil layer can naturally be found. For soil presenting high infiltration capacity, compaction through the use of machinery during construction works can limit soil permeability (Hamza and 
Anderson, 2005). On the other hand, installation of membranes (e.g., geotextile material) performs well to reduce downward infiltration but their cost can be prohibitive. Finally, addition of organic substrates could temporarily retain pesticide through partially reversible adsorption and can help reduce leaching (Huguenot et al., 2010).

\subsection{Open-Close strategy assessment}

Despite the small size of the $\mathrm{BZ}$ and although only a portion of the watershed outlet pesticide pollution was intercepted due to the open/close strategy, a significant improvement of drainage water quality was achieved. Pesticides transferred mainly with the first flows following applications were intercepted by the BZ. The relatively even distribution of water volume and pesticide load in the 2007-2008 was due to large storms occurring in spring 2008. The low intercepted loads for isoproturon over the whole monitoring period were mainly attributed to 2008-2009, during which flows were delayed due to a frost period occurring after pesticide applications. When flows resumed, the $\mathrm{BZ}$ were closed, thus preventing their interception. However, the largest isoproturon loads of the whole monitoring period were recorded in resuming flows, which had a substantial impact on the overall 2007-2010 isoproturon mass balance. Similarly for epoxiconazole (interception of $30 \%$ watershed outlet epoxiconazole loads for the 2007-2010 period), and unexpectedly, the highest loads were measured 15 months after the last application, even though the BZ were closed. Nevertheless, the overall results are very satisfactory as more than $39 \%$ of watershed outlet pesticide pollution did not return to the stream. This positive impact on downstream water quality was counter-balanced by a negative impact on the watershed hydrological cycle. From the 2007-2010 mass balance, it appeared that $25 \%$ of the watershed outlet volumes did not return to the stream due to increased evapotranspiration and possible vertical downward water losses resulting from buffer zone implementation (Table 3). It 
is arguable whether or not such water losses should be considered an issue. At the Bray watershed outlet, the permanent stream did not suffer from extended periods of low flows. However, such site-specific consequences on receiving aquatic ecosystem hydrology require serious consideration when setting up BZ.

\subsection{Uncertainty assessment}

The arbitrary choice of replacing nonquantifiable concentrations $(<\mathrm{LQ})$ by $\mathrm{LQ} / 2$ was the uncertainty source that exerted the largest influence on load values. At the watershed outlet, load uncertainties varied from 1 to $33 \%$ for $2007-2010$ loads depending on the pesticide molecules. Much larger uncertainties on loads were recorded for pesticides that were rarely quantified, e.g., aclonifen in the FB inlet $(0.07 \pm 0.15 \mathrm{~g})$ and outlet $(0.04 \pm 0.10 \mathrm{~g})$. However, for the most frequently quantified molecules, reasonable uncertainties were estimated, thus supporting the reliability of this large dataset.

\section{Conclusions}

This 3-yr field study highlighted the importance not only of the first flows following pesticide application, but those resuming after period of low or no flow, for transferring pesticide in tile-drained catchment. The data presented here demonstrated AW and FB potential for reducing pollution from certain pesticide molecules. Efficiency variability supports the idea that BZ should be part of a set of complementary approaches for pesticide pollution mitigation at the watershed level. It is recommended to set-up BZs as close to the pollution source as possible, in order to intercept and treat the most contaminated effluents while requiring smaller BZ surface areas than for diluted flows found in the lower portions of watersheds. For limited land availability as frequently encountered in Europe, placing BZ off-stream rather than in-stream 
gives the opportunity to implement smaller BZs operated by active water management strategies where the most contaminated flows are intercepted. A $0.5 \%$ ratio of $\mathrm{BZ}$ to watershed surface areas performed reasonably well when an active water management is conducted (herein referred to as an "open - close strategy"). Larger ratios of BZ to watershed areas (for example, 1 to $2 \%$ ) are recommended for pesticide mitigation if no active water management is implemented.

However, more research is needed to refine such design guidelines. Despite reversible adsorption was a crucial process governing pesticide fate in these systems, degradation could be substantial for longer residence times. This study showed that the overall impact of the combination of offstream BZ and the open/close strategy was very positive. Modeling buffer zone internal function may help further characterize pesticide transfer and reduction and optimize buffer zone design.

\section{Acknowledgement}

This research was financially supported by the European LIFE project ArtWET (06/ENV/F/000133).

Supplementary Material. Supplementary material associated with this article can be found, in the online version, at XXX.

\section{References}


Branger, F., Tournebize, J., Carluer, N., Kao, C., Braud, I., Vauclin, M., 2009. A simplified modelling approach for pesticide transport in a tile-drained field: The PESTDRAIN model. Agr. Water Manage. 96, 415-428.

Braskerud, B.C., Haarstad, K., 2003. Screening the retention of thirteen pesticides in a small constructed wetland. Water Sci. Technol. 48(5), 267-274.

Carter, A.D., 2000. Herbicide movement in soils: principles, pathways and processes. Weed Res. $40,113-122$.

Cote, C.M., Bristow, K.L., Ross, P.J., 2000. Increasing the efficiency of solute leaching: impacts of flow interruption with drainage of the "preferential flow paths". J. Contam. Hydrol. 43, 191209.

EURACHEM/CITAC, 2000. Guide CG 4. Quantifying Uncertainty in Analytical Measurement Second Edition.

FOOTPRINT, 2010. Pesticide Properties Database (PPDB) developed by the Agriculture \& Environment Research Unit (AERU), University of Hertfordshire, Hatfield, funded by UK and the EU-funded FOOTPRINT project (FP6-SSP-022704).

Gay, P., Vellidis, G., Delfino, J.J., 2006. The attenuation of atrazine and its major degradation products in a restored riparian buffer. T. ASABE 49, 1323-1339.

Gregoire, C., Elsaesser, D., Huguenot, D., Lange, J., Lebeau, T., Merli, A., Mose, R., Passeport, E., Payraudeau, S., Schütz, T., Schulz, R., Tapia-Padilla, G., Tournebize, J., Trevisan, M., 
Wanko, A., 2009. Mitigation of agricultural nonpoint-source pesticide pollution in artificial wetland ecosystems. Environ. Chem. Lett. 7, 205-231.

GUM, 1999. ISO Guide to the Expression of Uncertainty in Measurement (EN V 13-005), Sèvres, France.

Hamza, M.A., Anderson, W.K., 2005. Soil compaction in cropping systems: A review of the nature, causes and possible solutions. Soil Tillage Res. 82, 121-145.

Huguenot, D., Bois, P., Jézéquel, K., Cornu J.-Y., Lebeau, T., 2010. Selection of low cost materials for the sorption of copper and herbicides as single or mixed compounds in increasing complexity matrices. J. Hazard. Mater. 182, 18-26.

Imfeld, G., Braeckevelt, M., Kuschk, P., Richnow, H.H., 2009. Monitoring and assessing processes of organic chemicals removal in constructed wetlands. Chemosphere 74, 349-362.

Kadlec, R.H., Wallace, S.D., 2008. Treatment Wetlands. 2nd Ed. Boca Raton, FL.

Kladivko, E.J., Brown, L.C., Baker, J.L., 2001. Pesticide transport to subsurface tile drains in humid regions of North America. Crit. Rev. Env. Sci. Tec. 31, 1-62.

Kreuger, J., 1998. Pesticides in stream water within an agricultural catchment in southern Sweden, 1990-1996. Sci. Total Environ. 216, 227-251.

Lacas, J.G., Voltz, M., Gouy, V., Carluer, N., Gril, J.J., 2005. Using grassed strips to limit pesticide transfer to surface water: A review. Agron. Sustain. Dev. 25, 253-266.

Lowrance, R., Vellidis, G., Wauchope, R.D., Gay, P., Bosch, D.D., 1997. Herbicide transport in a managed riparian forest buffer system. T. ASAE 40, 1047-1057. 
Maillard, E., Payraudeau, S., Faivre, E., Gregoire, C., Gangloff, S., Imfeld, G., 2011. Removal of pesticide mixtures in a stormwater wetland collecting runoff from a vineyard catchment. Sci. Total Environ. 409, 2317-2324.

Moore, M.T., Kröger, R., Cooper, C.M., Smith, Jr. S., 2009. Ability of four emergent macrophytes to remediate permethrin in mesocosm experiments. Arch. Environ. Contam. Toxicol. 57, 282-288.

Moore, M.T., Rodgers, J.H., Cooper, C.M., Smith, S., 2000. Constructed wetlands for mitigation of atrazine-associated agricultural runoff. Environ. Pollut. 110, 393-399.

Passeport, E., Benoit, P., Bergheaud, V., Coquet, Y., Tournebize, J., 2011a. Selected pesticides adsorption and desorption in substrates from artificial wetland and forest buffer. Environ. Toxicol. Chem. 30, 1669-1676.

Passeport, E., Benoit, P., Bergheaud, V., Coquet, Y., Tournebize, J., 2011b. Epoxiconazole degradation from artificial wetland and forest buffer substrates under flooded conditions. Chem. Eng. J. 173, 760-765.

Passeport, E., Guenne, A., Culhaoglu, T., Moreau, S., Bouyé, J.-M., Tournebize, J., 2010 b. Design of experiments and detailed uncertainty analysis to develop and validate a solid-phase microextraction/gas chromatography-mass spectrometry method for the simultaneous analysis of 16 pesticides in water. J. Chromatogr. A 1217, 5317-5327.

Passeport, E., Tournebize, J., Jankowfsky, S., Promse, B., Chaumont, C., Coquet, Y., Lange, J., 2010a. Artificial wetland and forest buffer zone: hydraulic and tracer characterization. Vadose Zone J. 9, 73-84. 
Pinho, A.P., Matos, A.T., Morris, L.A., Costa, L.M., 2007. Atrazine and picloram adsorption in organic horizon forest samples under laboratory conditions. Planta Daninha 25, 125-131.

R Development Core Team, 2000. R: a Language and Environment for Statistical Computing. Vienna, Austria.

van der Valk, A.G., Jolly, R.W., 1992. Recommendations for research to develop guidelines for the use of wetlands to control rural nonpoint source pollution. Ecol. Eng. 1, 115-134.

Vellidis, G., Lowrance, R., Gay, P., Wauchope, R.D., 2002. Herbicide transport in a restored riparian forest buffer system. T. ASAE 45, 89-98. 
Figure legend

Fig. 1. Diagram of forest buffer (FB) and artificial wetland (AW) placement in the watershed (WS) showing inlet (in) and (outlet) flows.

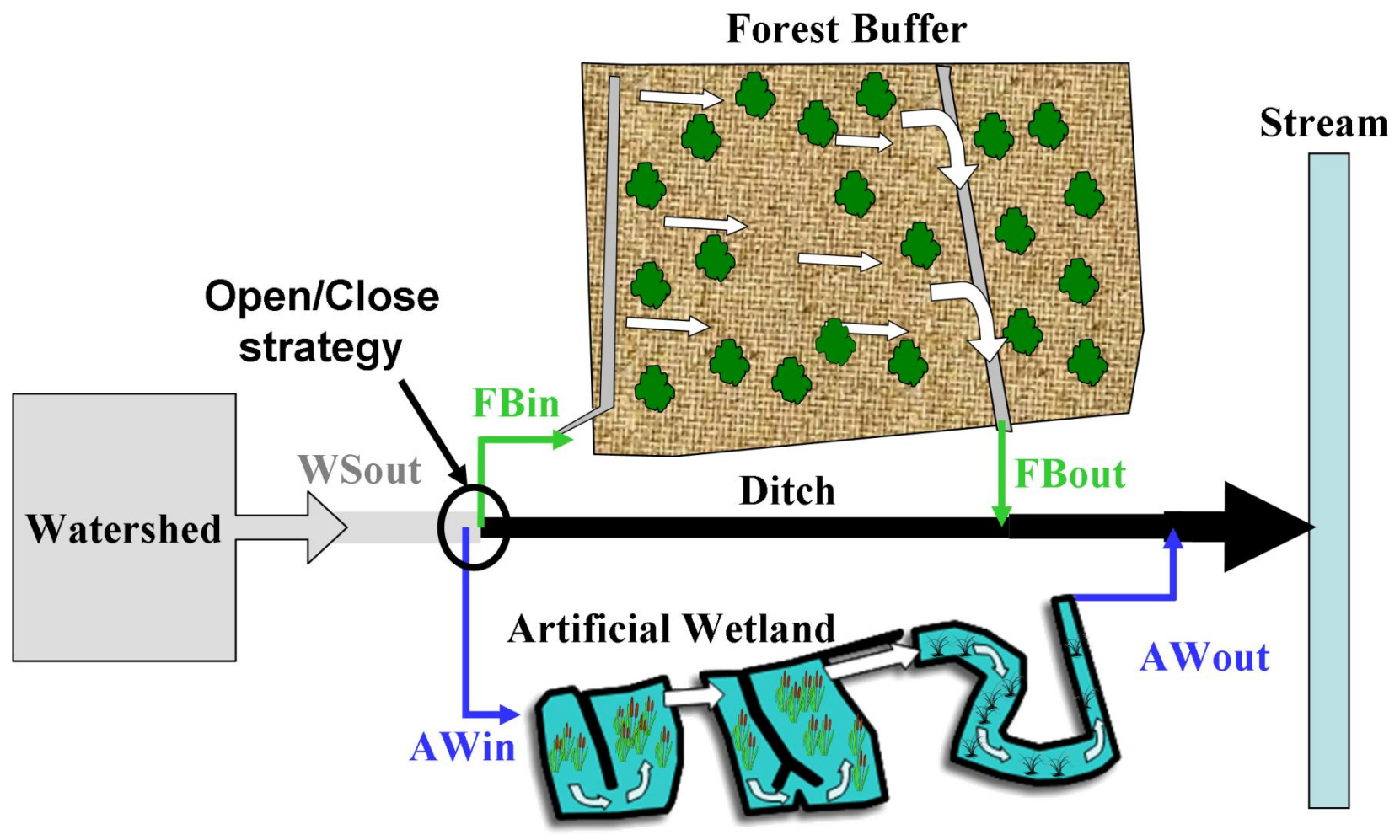


Fig. 2. Watershed outlet discharges $\left(\mathrm{L} \mathrm{s}^{-1} \mathrm{ha}^{-1}\right.$, grey dotted line), epoxiconazole (black line and circles) and metazachlor (grey line and triangles) concentrations $\left(\mu \mathrm{g} \mathrm{L}^{-1}\right)$. Figure (a) presents discharges and flow-weighted composite sample concentrations for the 3 -yr monitoring period (October 2007-May 2010). Figure (b) shows a zoom-in of figure (a) with discharges and timedependent sample concentrations taken over 1 wk after epoxiconazole application on 13 May 2009. Grey and black arrows indicate metazachlor (September 2007) and epoxiconazole (April and May 2008, May 2009 and May 2010) application dates by the farmer, respectively. Artificial wetland (AW) and forest buffer (FB) opening periods resulting from the implementation of the "open-close strategy" are indicated at the top of the graph. In addition, significant periods of frost ("Frost") are also indicated at the top of the graph. 

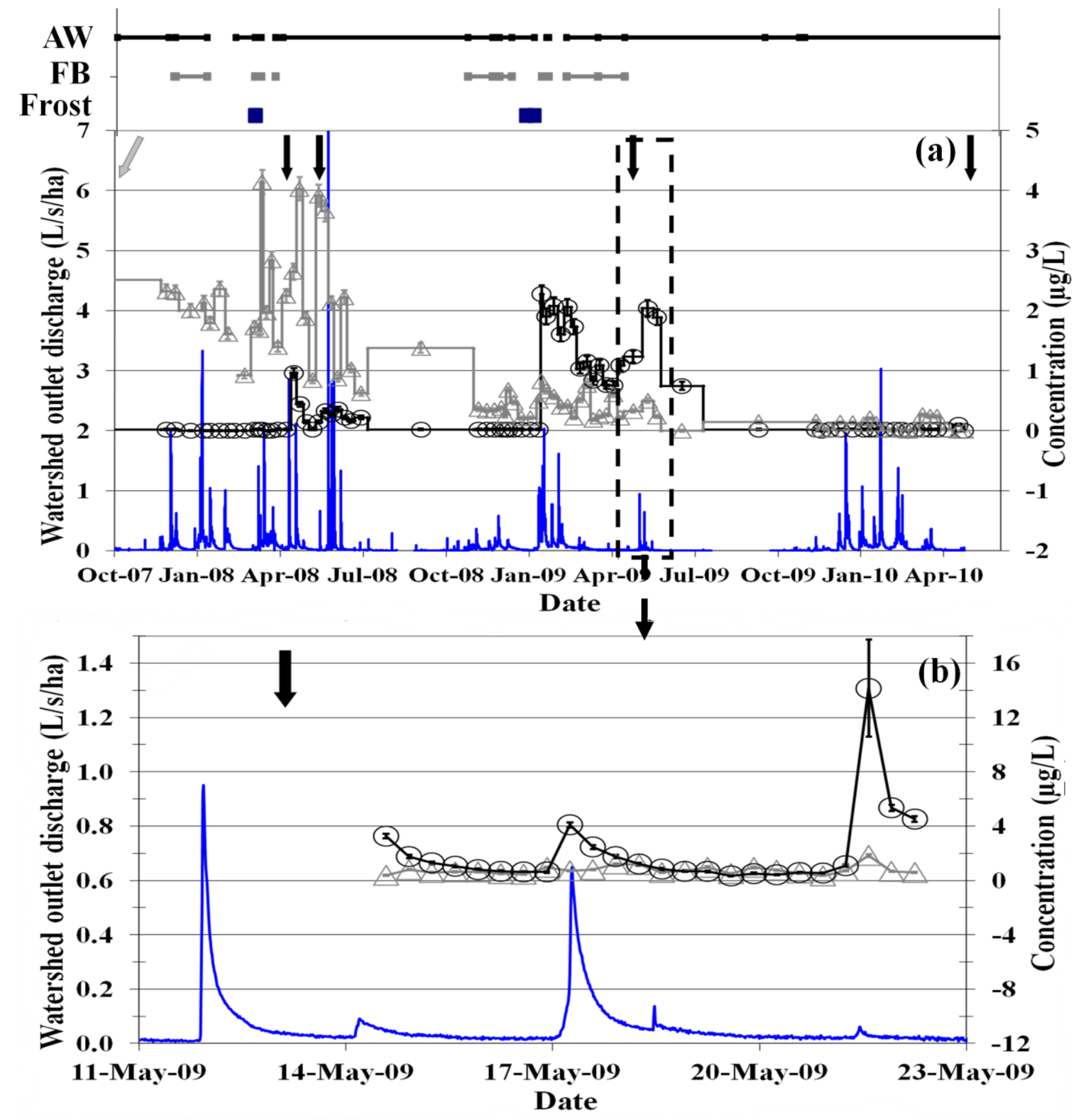
Table 1: Main characteristics for the 16 pesticides belonging to the SPME-GC/MS analytical method.

\begin{tabular}{|c|c|c|c|c|c|c|c|c|c|}
\hline \multirow[t]{2}{*}{ Pesticides } & $\begin{array}{c}\text { Log } \\
\mathrm{K}_{\mathrm{o} / \mathrm{w}} \\
\text { (a) }\end{array}$ & $\mathbf{K}_{\mathbf{o c}}^{(\mathbf{b})}$ & $\begin{array}{l}\mathrm{DT}_{50} \\
\text { field } \\
\text { (c) }\end{array}$ & $\begin{array}{l}\mathbf{D T}_{\mathbf{5 0}} \\
\text { sed }^{(\mathrm{c})}\end{array}$ & $\begin{array}{l}\mathbf{D T}_{\mathbf{5 0}} \\
\text { water }\end{array}$ & $\begin{array}{c}\text { Henry } \\
\text { constant (25 } \\
\left.{ }^{\circ} \mathrm{C}\right)\end{array}$ & $\begin{array}{c}\text { Water } \\
\text { solubilit } \\
\text { y }\left(20^{\circ} \mathrm{C}\right)\end{array}$ & $\mathbf{L} \mathbf{Q}^{(\mathbf{d})}$ & \multirow[t]{2}{*}{ Chemical group } \\
\hline & - & $\mathrm{mL} \mathrm{g}^{-1}$ & $d$ & d & $\mathrm{d}$ & $\mathrm{Pa} \mathrm{m}^{3} \mathrm{~mol}^{-1}$ & $\mathrm{mg} \mathrm{L}^{-1}$ & $\mu \mathrm{g} \mathrm{L}^{-1}$ & \\
\hline \multicolumn{10}{|l|}{ Herbicides } \\
\hline Atrazine & 2.7 & 100 & 29 & 80 & N/A & $1.50 \times 10^{-4}$ & 35 & 0.05 & Triazines \\
\hline Isoproturon & 2.5 & 122 & 23 & 149 & 40 & $1.46 \times 10^{-5}$ & 70.2 & 0.05 & Ureas \\
\hline Metazachlor & 2.49 & 134 & 6.8 & 20.6 & 216 & $5.90 \times 10^{-5}$ & 450 & 0.10 & Chloroacetamides \\
\hline Ethofumesate & 2.7 & 147 & 56 & 530 & 20 & $6.8 \times 10^{-4}$ & 50 & 0.10 & Benzofurans \\
\hline S-metolachlor & 3.4 & 200 & 21 & 365 & 88 & $2.40 \times 10^{-3}$ & 530 & 0.05 & Chloroacetamides \\
\hline Chlorotoluron & 2.5 & 205 & 34 & 352 & 42 & $1.44 \times 10^{-5}$ & 74 & 0.10 & Ureas \\
\hline Mefenpyr-diethyl & 3.83 & 634 & $17.5^{(a)}$ & 135 & 80 & $2.55 \times 10^{-4}$ & 20 & 0.05 & Pesticide safener \\
\hline Napropamide & 3.3 & 885 & 72 & 316 & 28 & $8.10 \times 10^{-5}$ & 74 & 0.05 & Alkanamides \\
\hline Prosulfocarb & 4.48 & 1693 & 9.8 & 214 & 1.05 & $1.52 \times 10^{-2}$ & 13.2 & 0.05 & Thiocarbamates \\
\hline Diflufenican & 4.2 & 3186 & 315 & 175 & N/A & $1.18 \times 10^{-2}$ & 0.05 & 0.05 & Carboxamides \\
\hline Aclonifen & 4.37 & 7126 & 117 & 14.3 & 4.2 & $3.03 \times 10^{-3}$ & 1.4 & 0.10 & Nitrophenyl ethers \\
\hline \multicolumn{10}{|l|}{ Fungicides } \\
\hline Cyproconazole & 3.09 & 309 & 191 & 300 & 300 & $5.0 \times 10^{-5}$ & 93 & 0.50 & Triazoles \\
\hline Tebuconazole & 3.7 & 769 & 55.8 & 365 & 42.6 & $1.0 \times 10^{-5}$ & 36 & 0.10 & Triazoles \\
\hline Chlorothalonil & 2.94 & 850 & 44 & 0.1 & 0.1 & $2.5 \times 10^{-2}$ & 0.81 & 0.50 & Chloronitriles \\
\hline Epoxiconazole & 3.3 & 1073 & 120 & 119.8 & 65.8 & $4.71 \times 10^{-4}$ & 7.1 & 0.10 & Triazoles \\
\hline Fenpropidine & 2.6 & 3808 & 49.2 & 34 & 1.8 & 10.7 & 530 & 0.05 & Morpholines \\
\hline
\end{tabular}


${ }^{(a)} \log \mathrm{K}_{\mathrm{o} / \mathrm{w}}$ : octanol/water partition coefficient; ${ }^{(b)} \mathrm{K}_{\mathrm{oc}}$ : sorption coefficient normalized to the organic content; ${ }^{(\mathrm{c})} \mathrm{DT}_{50 \mathrm{field}}, \mathrm{DT}_{50 \mathrm{sed}}$ and

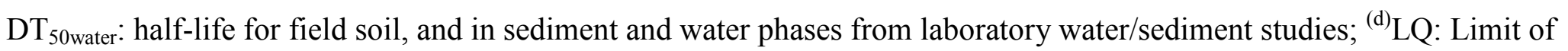
Quantification for the SPME-GCMS analytical method. All data (except for LQ) were obtained from FOOTPRINT (2010) 
Table 2: Concentration values at the watershed outlet during the 2007-2010 monitoring period.

\begin{tabular}{|c|c|c|c|c|c|c|}
\hline \multirow[t]{3}{*}{ Molecule } & \multicolumn{6}{|c|}{ Concentration values $\left(\mu \mathrm{g} \mathrm{L}^{-1}\right)$} \\
\hline & \multicolumn{6}{|c|}{ Buffer zone inlet $=$ watershed outlet $^{(\mathrm{a})}$} \\
\hline & $\operatorname{Min}^{(b)}$ & $\operatorname{Max}^{(\mathrm{c})}$ & Median & Mean & $\mathrm{SD}^{(\mathrm{d})}$ & $\mathrm{n}^{(\mathrm{e})}$ \\
\hline Isoproturon & 0.05 & 88 & 0.54 & 5.26 & 15.61 & 83 \\
\hline Chlorotoluron & 0.10 & 200 & 0.88 & 9.88 & 34.03 & 72 \\
\hline Atrazine & 0.05 & 0.25 & 0.03 & 0.03 & 0.04 & 26 \\
\hline Chlorothalonil & 0.50 & 0.25 & 0.25 & 0.25 & 0.00 & 34 \\
\hline Prosulfocarb & 0.05 & 2.12 & 0.03 & 0.32 & 0.62 & 22 \\
\hline Fenpropidin & 0.05 & 0.09 & 0.03 & 0.03 & 0.01 & 46 \\
\hline Ethofumesate & 0.10 & 0.92 & 0.05 & 0.15 & 0.23 & 23 \\
\hline S-metolachlor & 0.05 & 0.07 & 0.03 & 0.03 & 0.01 & 25 \\
\hline Metazachlor & 0.10 & 4.15 & 0.50 & 1.00 & 1.08 & 72 \\
\hline Napropamide & 0.05 & 0.25 & 0.03 & 0.04 & 0.05 & 56 \\
\hline Cyproconazole & 0.50 & 0.25 & 0.25 & 0.25 & 0.00 & 27 \\
\hline Aclonifen & 0.10 & 1.11 & 0.05 & 0.18 & 0.33 & 10 \\
\hline Diflufenican & 0.05 & 0.64 & 0.03 & 0.06 & 0.10 & 74 \\
\hline Tebuconazole & 0.10 & 1.07 & 0.05 & 0.10 & 0.18 & 48 \\
\hline Mefenpyr-dietyl & 0.05 & 2.19 & 0.03 & 0.09 & 0.36 & 36 \\
\hline Epoxiconazole & 0.10 & 2.27 & 0.05 & 0.45 & 0.66 & 65 \\
\hline
\end{tabular}


${ }^{(a)}$ Sampling equipment at buffer zone inlet corresponds to watershed outlet. ${ }^{(b)}$ Min: minimal value, ${ }^{(c)}$ Max: maximal value, ${ }^{(d)} \mathrm{SD}$ : standard deviation (data dispersion), and ${ }^{(\mathrm{e})} \mathrm{n}$ : number of concentration values. 
Table 3: Artificial wetland (AW), forest buffer (FB) and watershed (WS) loads and ${ }^{(a)}$ load reductions for the whole 2007-2010 monitoring period, for the 16 pesticides belonging to the analytical method.

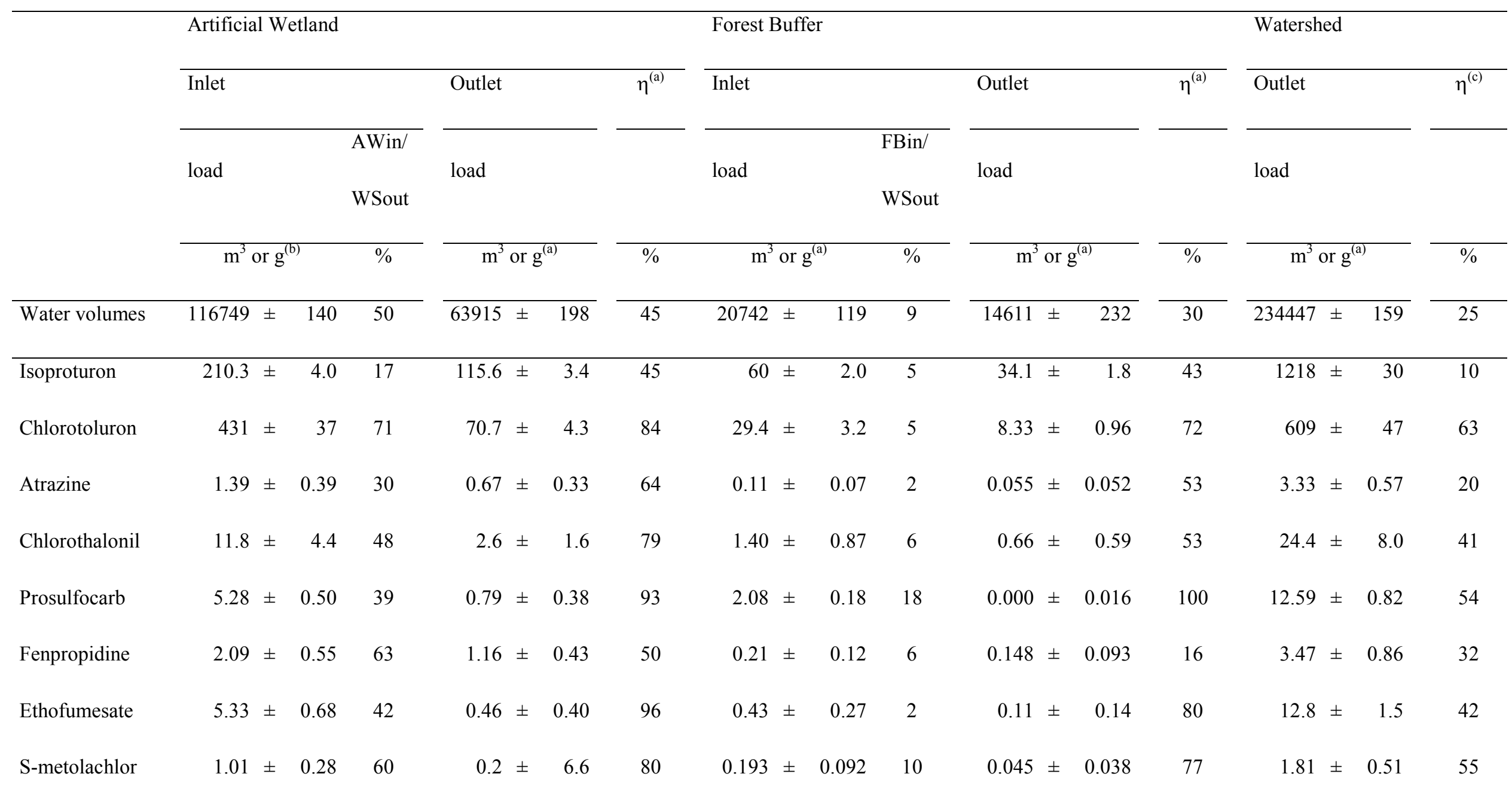




\begin{tabular}{|c|c|c|c|c|c|c|c|c|c|c|c|c|c|c|c|c|c|c|c|}
\hline Metazachlor & 111.5 & \pm & 1.6 & 40 & 34.12 & $\pm \quad 0.95$ & 70 & 28.67 & \pm & 0.72 & 10 & 19.09 & \pm & 0.59 & 33 & 277.7 & \pm & 3.3 & 32 \\
\hline Napropamide & 3.72 & \pm & 0.52 & 66 & 1.39 & $\pm \quad 0.36$ & 65 & 0.62 & \pm & 0.20 & 9 & 0.30 & \pm & 0.16 & 67 & 6.08 & \pm & 0.87 & 49 \\
\hline Cyproconazole & 14.4 & \pm & 4.9 & 63 & 8.0 & 3.4 & 44 & 0.55 & \pm & 0.25 & 2 & 0.67 & \pm & 0.73 & -32 & 23.1 & \pm & 7.3 & 27 \\
\hline Aclonifen & 2.54 & \pm & 0.48 & 85 & 0.59 & $\pm \quad 0.33$ & 80 & 0.07 & \pm & 0.15 & 1 & 0.04 & \pm & 0.10 & 34 & 3.40 & \pm & 0.97 & 69 \\
\hline Diflufenican & 6.10 & \pm & 0.58 & 68 & 1.95 & $\pm \quad 0.43$ & 75 & 0.78 & \pm & 0.21 & 7 & 0.40 & \pm & 0.16 & 56 & 9.9 & \pm & 1.0 & 55 \\
\hline Tebuconazole & 7.4 & \pm & 1.0 & 36 & 1.39 & $\pm \quad 0.65$ & 86 & 2.53 & \pm & 0.44 & 14 & 0.82 & \pm & 0.26 & 70 & 19.7 & \pm & 2.3 & 41 \\
\hline Mefenpyr-dietyl & 4.61 & \pm & 0.55 & 21 & 1.15 & $\pm \quad 0.32$ & 80 & 0.23 & \pm & 0.11 & 1 & 0.075 & \pm & 0.050 & 70 & 18.7 & \pm & 1.3 & 17 \\
\hline Epoxiconazole & 26.3 & \pm & 1.5 & 28 & 8.11 & 1.0 & 71 & 2.20 & \pm & 0.34 & 2 & 0.65 & \pm & 0.25 & 76 & 90.1 & \pm & 3.8 & 21 \\
\hline Mean & & & & 49 & & & 73 & & & & 6 & & & & 54 & & & & 39 \\
\hline Median & & & & 45 & & & 77 & & & & 5 & & & & 61 & & & & 41 \\
\hline Standard Deviation & & & & & & & 16 & & & & & & & & 31 & & & & 17 \\
\hline
\end{tabular}

${ }^{(b)}$ Water volumes $\left(\mathrm{m}^{3}\right)$ and pesticide loads (g) are provided at the inlet (in) and outlet (out) of the systems. ${ }^{(\mathrm{c})}$ Reduction of the watershed load corresponds to the portion of pesticides that was actually dissipated through the two buffer zones and did not reach the stream. 


\title{
Pesticide contamination interception strategy and
}

\author{
removal efficiency in forest buffer and artificial
}

\section{wetland in a tile-drained agricultural watershed}

*Elodie PASSEPORT ${ }^{\mathrm{a}, 1}$, Julien TOURNEBIZE ${ }^{\mathrm{a}}$, Cédric CHAUMONT ${ }^{\mathrm{a}}$, Angeline GUENNE ${ }^{\mathrm{a}}$, Yves COQUET $^{\mathrm{b}}$

${ }^{a}$ Research Unit Hydrosystems and Bioprocesses, IRSTEA, 1 rue Pierre-Gilles de Gennes, CS 10030, 92761 Antony Cedex, France

${ }^{\mathrm{b}}$ AgroParisTech, UMR 1091 EGC, BP 01, 78850 Grignon, France.

\section{Corresponding Author}

*passeport@es.utoronto.ca

${ }^{1}$ Present address : University of Toronto, 22 Russell St, Earth Science Center 1066, Toronto, Ontario M5S 3B1, Canada. Phone: 001 416-978-0549. Fax: 001 416-978-3839. 
Fig. SM-1

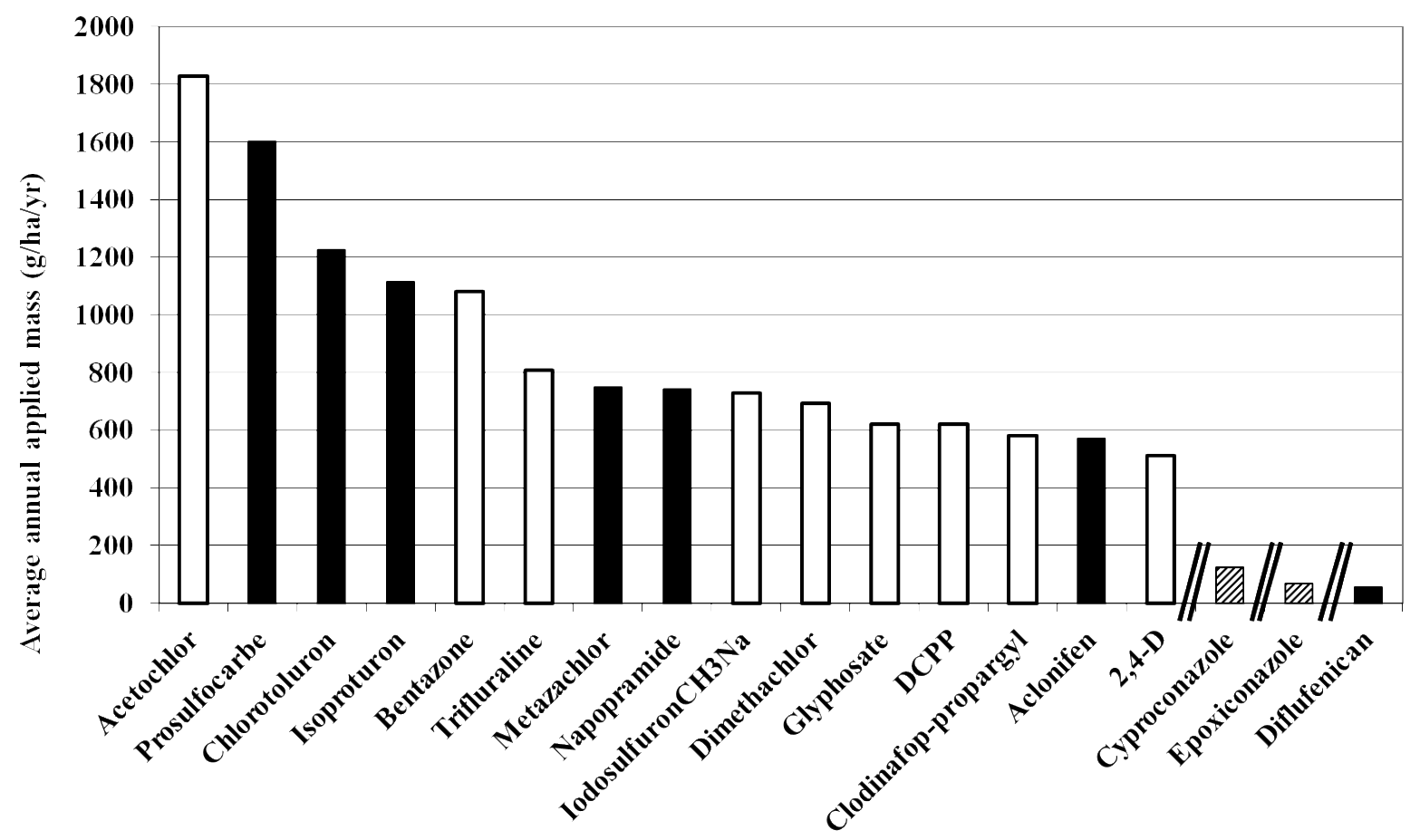

Average yearly applied mass (in $\mathrm{g} \mathrm{ha}^{-1} \mathrm{yr}^{-1}$ ) for the most frequently used pesticides on the Bray catchment, whether they belong to the analytical method used in this study (full black bars (herbicides), and those with hatchings (fungicides)) or not (white bars). 
Fig. SM-2

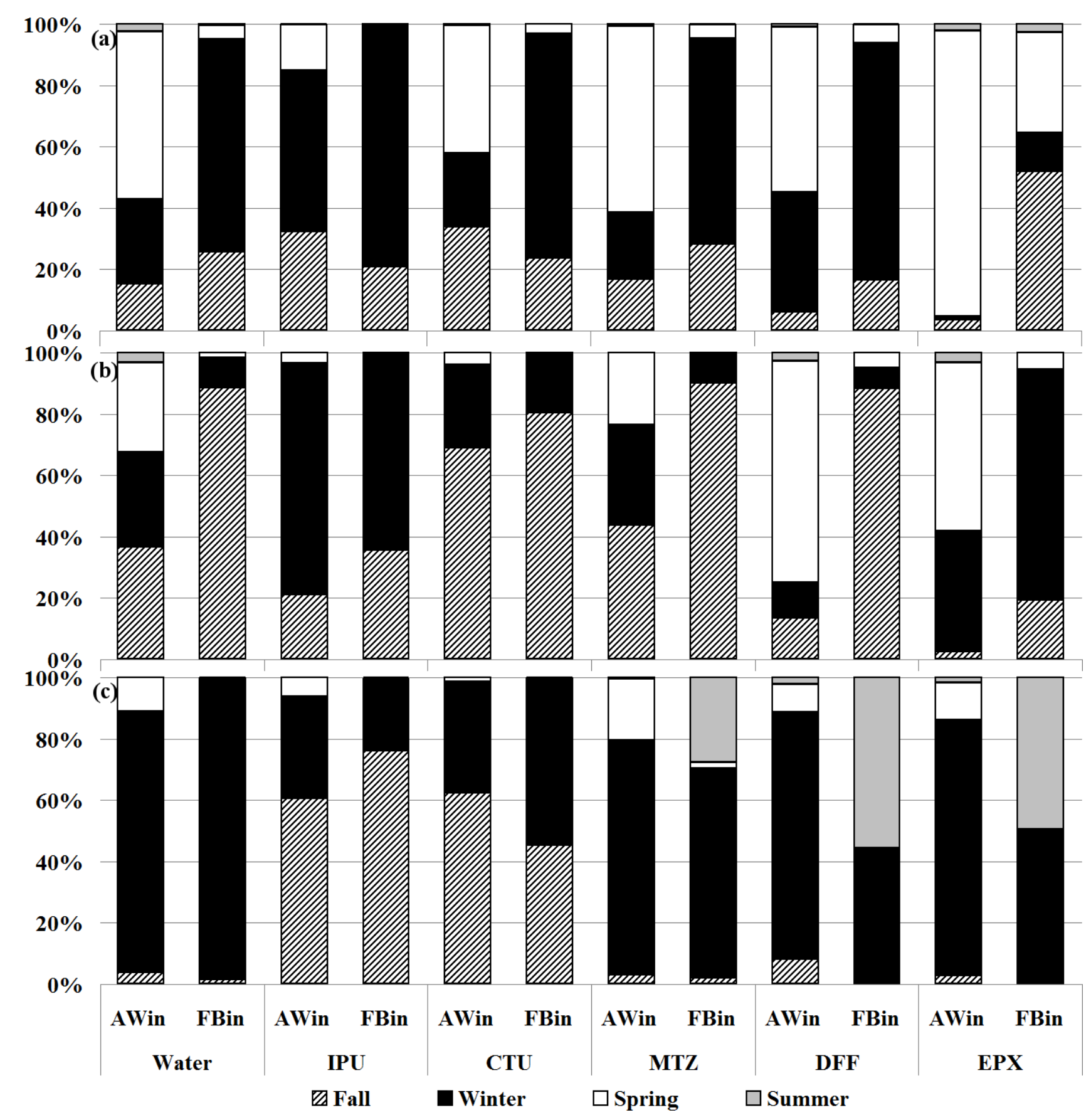

Distribution of water volumes (Water) or loads for isoproturon (IPU), chlorotoluron (CTU), metazachlor (MTZ), diflufenican (DFF) and epoxiconazole (EPX) in fall (hatchings), winter 
(black), spring (white) and summer (grey) for the artificial wetland inlet (AWin) and the forest buffer inlet (FBin) for the (a) 2007-2008, (b) 2008-2009 and (c) 2009-2010 hydrologic years.

Fig. SM-3 


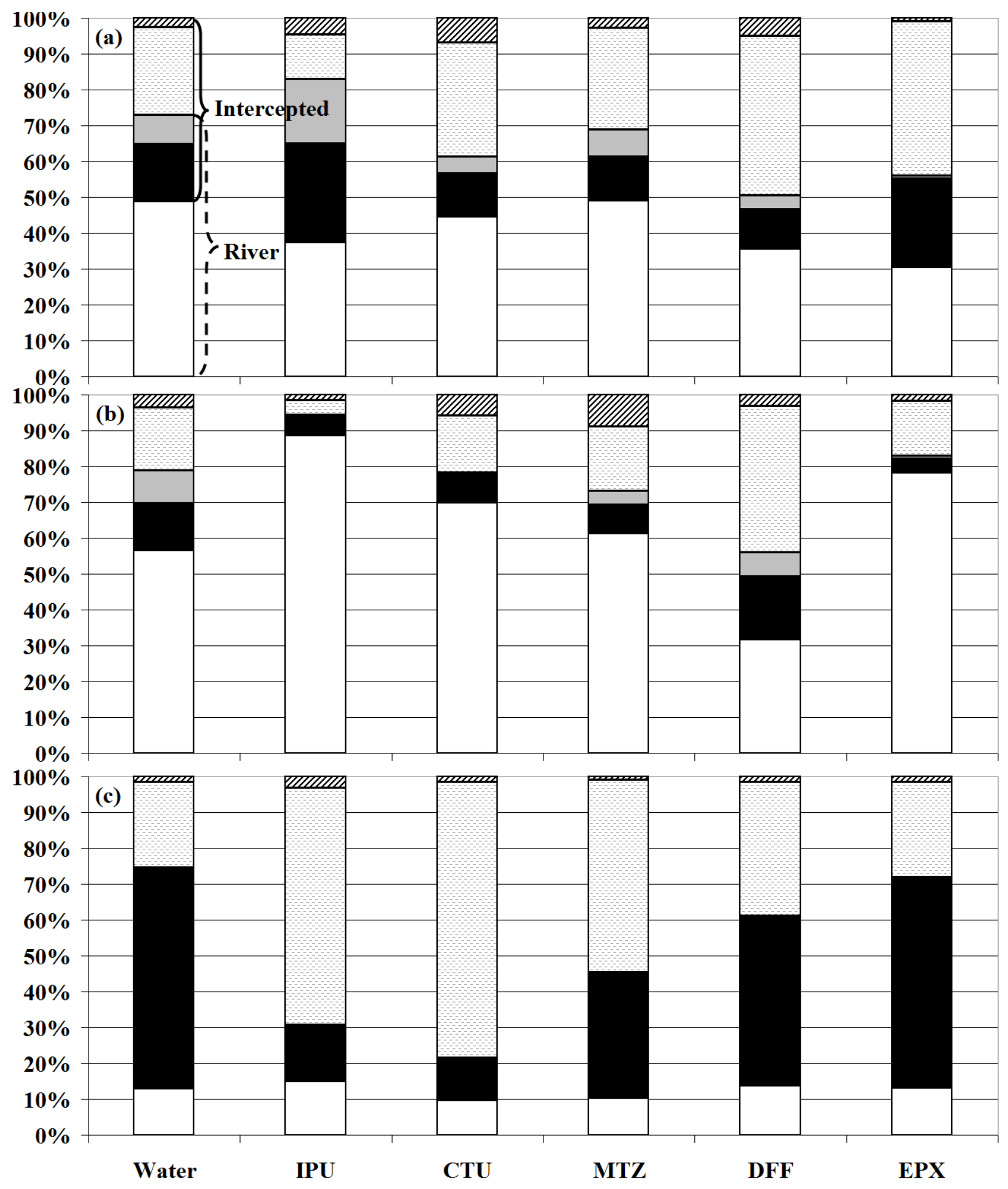

$\square$ Ditch $\square$ AWout $\square$ FBout $\quad$ AW removed $\square$ FB removed 
Distribution of watershed outlet (100\%) water volumes (Water) or loads for isoproturon (IPU), chlorotoluron (CTU), metazachlor (MTZ), diflufenican (DFF) and epoxiconazole (EPX) into the agricultural ditch (Ditch, white), the parts crossing the systems and measured at the artificial wetland outlet (AWout, black) and the forest buffer outlet (FBout, grey) and the portions removed in the artificial wetland (AW removed, dashes) and the forest buffer (FB removed, hatchings) for the (a) 2007-2008, (b) 2008-2009 and (c) 2009-2010 hydrologic years. The sum of AWout, FBout, AW removed and FB removed corresponds to the portions passing through or intercepted by the buffer zones due to the implementation of the open/close strategy (Intercepted), whereas the sum of Ditch, AWout and FBout corresponds to the portions returning to the river (River). 


\section{Table SM-1}

\begin{tabular}{|c|c|c|c|c|c|c|c|c|c|c|c|c|}
\hline \multirow[t]{3}{*}{ Molecule } & \multicolumn{12}{|c|}{ Concentration reductions (\%) } \\
\hline & \multicolumn{6}{|c|}{ Artificial wetland } & \multicolumn{6}{|c|}{ Forest buffer } \\
\hline & $\operatorname{Min}^{(a)}$ & $\operatorname{Max}^{(b)}$ & Median & Mean & $\mathrm{SD}^{(\mathrm{c})}$ & $\mathrm{n}_{\mathrm{p}}^{(\mathrm{d})}$ & $\operatorname{Min}^{(a)}$ & $\operatorname{Max}^{(b)}$ & Median & Mean & $\mathrm{SD}^{(\mathrm{c})}$ & $\mathrm{n}_{\mathrm{p}}^{(\mathrm{d})}$ \\
\hline Isoproturon & -382 & 83 & -9 & -28 & 103 & 33 & -138 & 100 & 21 & -2 & 89 & 8 \\
\hline Chlorotoluron & -108 & 100 & 31 & 29 & 53 & 34 & 30 & 100 & 65 & 71 & 26 & 11 \\
\hline Atrazine & 100 & 100 & 100 & 100 & n.a. & 1 & n.a. & n.a. & n.a. & n.a. & n.a. & 0 \\
\hline Chlorothalonil & n.a. & n.a. & n.a. & n.a. & n.a. & 0 & n.a. & n.a. & n.a. & n.a. & n.a. & 0 \\
\hline Prosulfocarb & 56 & 56 & 56 & 56 & n.a. & 1 & n.a. & n.a. & n.a. & n.a. & n.a. & 0 \\
\hline Fenpropidin & 52 & 52 & 52 & 52 & n.a. & 1 & n.a. & n.a. & n.a. & n.a. & n.a. & 0 \\
\hline Ethofumesate & 60 & 100 & 93 & 85 & 21 & 3 & n.a. & n.a. & n.a. & n.a. & n.a. & 0 \\
\hline S-metolachlor & 63 & 63 & 63 & 63 & n.a. & 1 & n.a. & n.a. & n.a. & n.a. & n.a. & 0 \\
\hline Metazachlor & -62 & 100 & 42 & 34 & 59 & 32 & -62 & 100 & 42 & 48 & 46 & 14 \\
\hline Napropamide & 6 & 12 & 9 & 9 & 4 & 2 & n.a. & n.a. & n.a. & n.a. & n.a. & 0 \\
\hline Cyproconazole & n.a. & n.a. & n.a. & n.a. & n.a. & 0 & n.a. & n.a. & n.a. & n.a. & n.a. & 0 \\
\hline
\end{tabular}




\begin{tabular}{|c|c|c|c|c|c|c|c|c|c|c|c|c|}
\hline Aclonifen & 40 & 79 & 59 & 59 & 27 & 2 & 15 & 15 & 15 & 15 & n.a. & 1 \\
\hline Diflufenican & 14 & 100 & 50 & 56 & 33 & 9 & 18 & 100 & 58 & 58 & 46 & 4 \\
\hline Tebuconazole & -106 & 100 & 79 & 48 & 78 & 6 & 65 & 67 & 66 & 66 & 1 & 2 \\
\hline Mefenpyr-dietyl & 42 & 42 & 42 & 42 & n.a. & 1 & n.a. & n.a. & n.a. & n.a. & n.a. & 0 \\
\hline Epoxiconazole & -191 & 100 & 30 & 8 & 78 & 10 & -15 & 100 & 42 & 42 & 81 & 2 \\
\hline Mean & & & & 44 & & & & & & 43 & & \\
\hline $\mathrm{SD}^{(\mathrm{c})}$ & & & & 32 & & & & & & 27 & & \\
\hline Mean $\left(\mathrm{n}_{\mathrm{p}}{ }^{(\mathrm{d})}>6\right)$ & & & & 25 & & & & & & 39 & & \\
\hline $\mathrm{SD}^{(\mathrm{c})}\left(\mathrm{n}_{\mathrm{p}}^{(\mathrm{d})}>6\right)$ & & & & 30 & & & & & & 37 & & \\
\hline
\end{tabular}

Concentration reductions during the 2007-2010 monitoring period. ${ }^{(a)}$ Min: minimal value, ${ }^{(b)}$ Max: maximal value, ${ }^{(c)}$ SD: standard deviation (data dispersion), and ${ }^{(\mathrm{d})} \mathrm{n}_{\mathrm{p}}$ : number of inlet-outlet synchronic pairs of samples. 